$125 \cdot 1]$

\title{
Hegel contra Schlegel; Kierkegaard contra de Man
}

\author{
AYON ROY
}

AYON ROY is a PhD candidate in English at the University of California, Berkeley. This essay derives from his dissertation, "The After of Art: Kant, Hegel, and the Dialectics of Aesthetic Irony." His articles on poetry and philosophy have appeared or are forthcoming in the Journal of the History of Ideas, the Wallace Stevens Journal, Arizona Quarterly, Gingko Tree Review, and Epoché: A Journal for the History of Philosophy.
Irony as the negative is the way; it is not the truth but the way. -Søren Kierkegaard, The Concept of Irony ${ }^{1}$

\section{《6}

RONY IS A PERMANENT PARABASIS." THIS CRYPTIC DECLARATION was made in 1797 by Friedrich Schlegel, the German Romantic writer who inaugurated modern discourse on irony. ${ }^{2}$ In ancient Greek drama, parabasis is the moment when the continuity of the dramatic narrative is disrupted by the sudden intrusion of the playwright. By bringing the dramatic device of parabasis into violent confrontation with the rhetorical trope of irony, Schlegel forces both concepts to exceed their respective parameters. In Schlegel's hands, irony explodes its rhetorical confines, widening into a philosophical and existential category. ${ }^{3}$ Irony as a permanent parabasis, then, seems to be nothing less than the abyssal operation by which any claim to stability or continuity-be it artistic, philosophical, or existential-is incessantly undermined. Indeed, as Schlegel emphasized in "On Incomprehensibility," his 1800 metaessay on irony, one of irony's basic features is its permanently disruptive force: its refusal to be neatly defined or circumscribed, its uncanny tendency to proliferate endlessly into further ironies. At the essay's climax, he gave voice to a question that has lost none of its urgency more than two centuries after it was first posed: "What gods will be able to rescue us from all these ironies?"

Recent critics have devoted inordinate attention to Schlegel's theory of irony not least because of its startling resonances with some of the central concerns of postmodernity. In his influential 1977 essay "The Concept of Irony," Paul de Man makes a persuasive case for conceiving Schlegel's theory of irony as a bold anticipation of

(C) 2009 BY THE MODERN LANGUAGE ASSOCIATION OF AMERICA 
poststructuralism. For de Man, irony as the radically diachronic operation of permanent parabasis is a proto-form of Jacques Derrida's principle of différance, which always already interrupts-or differs and defers-any purportedly synchronic claim to sheer immediacy or self-presence. The virtuosity of "The Concept of Irony" consists in de Man's sustained effort to anchor his poststructuralist interpretation of Schlegel's theory of irony in a provocative and subtle revaluation of some of the key figures in modern philosophy: Johann Gottlieb Fichte, Georg Wilhelm Friedrich Hegel, and Søren Kierkegaard. As de Man recognized, how we interpret Schlegel's theory of irony has far-reaching implications for philosophical and critical discourse more generally.

A brief survey of the reception of Schlegel's theory of irony from Hegel up to the present will help us situate and assess de Man's poststructuralist approach to Schlegel. Shortly after Schlegel presented his theory of irony in the journals Lyceum and Athenaeum between 1797 and 1800, his contemporary Hegel launched a bitterly polemical campaign against Schlegel by trying to demonstrate that beneath Schlegel's reveling in the abyssal, vertiginous dimension of irony lurked a hyperinflated ego modeled on the absolute Ich at the basis of Fichte's philosophy. In his 1841 doctoral dissertation, The Concept of Irony, the young Kierkegaard attempted singlehandedly to raise this apparently harmless feud into a matter of world-historical significance. On the one hand, Kierkegaard conceded the force of Schlegel's theory of irony and made a powerful case for conceiving it as the fundamental principle of a disenchanted modernity. On the other hand, he tried to recover a substantive critique of irony from $\mathrm{He}-$ gel's polemics against Schlegel and ultimately sided with Hegel in arguing for the need to overcome the ironic stance.

Curiously, however-with the important exceptions of the early Walter Benjamin and Georg Lukács-virtually no commentator on
Romantic irony in the twentieth century (and up to the present) has been willing to approach the Hegel-Schlegel debate from a broadly Kierkegaardian perspective that would seek to honor the competing claims of both parties. ${ }^{5}$ While Schlegel's theory of irony has generated seemingly endless commentary in recent critical discourse, Hegel's critique of Schlegel has tended to be ignored or, at best, summarily dismissed as little more than a historical curiosity. Indeed, Oskar Walzel's 1938 pronouncement can be said to have set the tone for nearly all subsequent treatments of Hegel's agon with Schlegel: "A quite great man, Hegel, speaks falsely out of blind hate about F. Schlegel's romantic irony." "In "The Concept of Irony," de Man clearly participates in this general trend when, instead of engaging the details of $\mathrm{He}$ gel's critique of Schlegel, he dismisses Hegel's critique wholesale as a spurious attempt to "defuse" irony by reducing it to a moment in "a dialectics of history" (170).

The widespread neglect of Hegel's critique of Schlegel in recent criticism can be attributed in part to a burgeoning interest in Schlegel's complex stance toward Fichte's post-Kantian idealist philosophy. By making subtle use of Schlegel's copious philosophical writings, recent critics have drawn our attention to the various ways Schlegel breaks with, and makes significant advances over, Fichte.? Ernst Behler, the most important contemporary Schlegel critic, is typical in dating Schlegel's break with Fichte as early as 1796, a year before Schlegel even begins to develop his theory of irony (Ironie 143). ${ }^{8}$ This trend in recent scholarship has made it very easy to dismiss Hegel's apparently straightforward attribution of Fichtean subjectivism to Schlegel's theory of irony-a dismissal that, in turn, seems to render irrelevant Hegel's polemical critique of irony itself.

The guiding conviction of this essay, however, is that critics have been too quick to dismiss Hegel's so-called dismissal of Schlegel. To make my case, I will focus on an aspect of 
Schlegel's engagement with Fichte largely ignored by recent criticism: Schlegel's complex stance toward the philosophical category of intuition (Anschauung). ${ }^{9}$ In the first two sections of this essay, I hope to establish that the Fichtean category of intuition plays a significant role in Schlegel's theory of irony and in his philosophical thinking more generally. Schlegel's philosophical lectures delivered between 1800 and 1805 betray an aporetic stance toward intuition: despite conscious efforts to repudiate the category, Schlegel ultimately remains committed to Fichte's intuitional epistemology. ${ }^{10}$ This will lay the groundwork for the third section, where I seek to resuscitate the subtlety and force of Hegel's critique of Schlegel's theory of irony. I argue that the primary target of Hegel's critique is precisely the unexamined epistemology of intuition at the basis of Schlegel's theory.

In the course of this essay, I hope cumulatively to demonstrate that de Man is guilty of what might be called a poststructuralist defusing of irony. De Man's dismissal of Hegel's critique of Schlegel proves to be sponsored by a series of interpretive moves that depend on the strategic suppression of manifold complexities in Schlegel's theory of irony, Fichte's account of the absolute Ich, and Schlegel's ambivalent stance toward Fichte. In the essay's final section, I suggest that de Man's insights in "The Concept of Irony" can be traced to a curiously willed moment of blindness: his persistent refusal to honor Kierkegaard's distinctive contribution to modern discourse on irony. Kierkegaard's subtle recasting of Hegel's critique of Schlegel, I argue, can be mobilized as a powerful challenge both to standard poststructuralist-inflected critiques of Hegelian dialectics and to the hermeneutics of suspicion dominating contemporary literary studies.

\section{Schlegel's Epistemology of Irony}

In 1797 Schlegel characterized irony as "a permanent parabasis"-a formulation that goes a long way toward illuminating the basic logic of his concept of irony, although it can hardly be taken as definitive. In fact, between 1797 and 1800 Schlegel felt compelled to define and redefine irony in ever stranger and more cryptic formulations scattered throughout issues of the journals Lyceum and Athenaeum. It can be said that much of the complexity of Schlegel's theory of irony derives from his constant vacillation between characterizations of the inner logic of irony as such and descriptions of the ironist's mood or state of mind. ${ }^{11}$ Schlegel encounters a unique problem in describing the ironist: how is it possible to offer an account of irony that does not illegitimately exempt the ironist from the operation of parabasis? In other words, any description of the ironist seems haunted by the self-contradiction that such an account requires smuggling in a stable subject position that goes unironized. In the famous fragment 42 in his 1797 Lyceum Fragments, Schlegel registers an acute awareness of this dilemma. Irony is presented there as "the mood that surveys everything and rises infinitely above all that is conditioned, even above its own art, virtue, or genius." 12 If the ironist truly rises above all that is conditioned, Schlegel realizes, then it will not do to assume that the ironist's subject position is somehow unconditioned. Hence, the final clause of this formulation insists that the ironic mood rises above even its own art, virtue, or genius. Yet this approach to handling the dilemma seems plagued by an infinite regress, for the subject position of the ironist can in turn be ironized only from a still-higher subjective standpoint that remains unironized.

Schlegel's ingenious strategy for handling this problem is to build infinite regress into his conception of irony: irony becomes, paradoxically, the radicalization of regress itself, a regress made reflexively aware of its status as regress. In "On Incomprehensibility," Schlegel revels in what he calls "the irony of irony" ("die Ironie der Ironie”), irony's relentless tendency to regress into higher-order ironies 
(Charakteristiken 369). To begin to appreciate the centrality of the problem of regress in Schlegel's theory of irony, we should consider Lyceum fragment 48 , where Schlegel defines irony as "the form of paradox" ("der Form des Paradoxen"; 153). In Lyceum fragment 108 , irony's paradoxical form is more specifically articulated as containing and arousing "a feeling of indissoluble antagonism between the unconditioned and the conditioned." ${ }^{13}$ In other words, far from rising above the realm of the conditioned by straightforwardly inhabiting a higher, purportedly unconditioned standpoint, the ironist faces the more daunting challenge of inhabiting both realms at once-or, at least, shuttling constantly between them. Not surprisingly, in the Athenaeum Fragments Schlegel repeatedly describes irony as a kind of shuttling or hovering between antithetical extremes. In Athenaeum fragment 51, for instance, irony is characterized as the "constant alternation of self-creation and self-destruction."14 Behler convincingly argues that this "rhythm of selfcreation and self-destruction, of enthusiasm and skepticism" is the "fundamental characteristic of Schlegel's conception of irony." 15

Hence, there seem to be three basic coordinates in Schlegel's theory of irony: the two first-order ironies of enthusiasm and skepticism and the second-order irony of irony, which oscillates continually between the firstorder ironies. This master frame helps foreground an aspect of Schlegel's theory of irony largely neglected in the critical literature: his occasional linkage of irony with intuition, one of the key categories in post-Kantian idealist epistemology.

We can begin to explore irony's curious affiliation with intuition by comparing two of Schlegel's formulations of irony that are almost, but not quite, identical. In his 1800 Ideen fragment 69 , contained in the penultimate issue of the Athenaeum, Schlegel vividly describes second-order irony: "Irony is clear consciousness of eternal agility, of the infinitely teeming chaos."16 One could object, however, that this formulation proves insufficiently aware of the regress problem in that it sets up too sharp a contrast between the stable, unironized subject position of the ironist's clear consciousness and the infinitely teeming chaos of which the ironist is conscious. A year or two earlier, in an underdiscussed fragment in his Philosophische Lehrjahre, Schlegel offers a subtly different formulation of irony that handles the regress problem by collapsing the distance between the ironist and that which is ironized: "Irony is clear $\chi \alpha$ [chaos] in agility, intellectual intuition of an eternal $\chi \alpha . \ldots . " 17$ If in the Ideen formulation irony is defined as the clear consciousness of chaos, in this earlier, violently paradoxical formulation, the genitive disintegrates: irony is clear $\chi \alpha$, that explosive point at which clarity and chaos impossibly meet. In the next clause, Schlegel invokes the Fichtean category of intellectual intuition as a means of conveying this radical ironizing of the very distance between the ironist and the ironist's medium.

In his 1800 Dialogues on Poetry, published in the same Athenaeum issue as Ideen, Schlegel once again characterizes irony in terms of intuition: "We therefore adhere only to the meaning of the Whole; what stimulates, moves, occupies, and amuses individually the sense, the heart, the understanding, and the imagination appears to us only as a figure, a means to the intuition of the Whole, to which we raise ourselves in an instant." ${ }^{\text {"18 }}$ Notice that this formulation is structurally identical to Schlegel's 1797 definition of irony as a "mood" that rises above everything conditioned. In this case, the realm of the conditioned becomes a realm of mere figures, and the mechanism by which the ironist rises above this realm is an instantaneous intuition of a rather mysterious Whole. (Not surprisingly, it is precisely this synchronic dimension of Schlegel's theory of irony that gets suppressed in de Man's account.) At this point, it should remain an open question whether Schlegel's 
invocation of intuition really avoids the regress problem or simply masks it: by what right, after all, does Schlegel exempt this intuition of the Whole from ironic parabasis?

As far as I am aware, these are the only two formulations in Schlegel's entire corpus in which irony is explicitly linked to the faculty of intuition. However, this affiliation of irony with intuition gains significance once we note the frequency of Schlegel's invocation of intuition throughout the Athenaeum. Intuition (Anschauung) and intellectual intuition (intellektuale Anschauung) are frequently exalted in the Athenaeum as faculties capable of overcoming the limitations of rational or discursive modes of thought. ${ }^{19}$ The exemplary passage in this regard has to be Schlegel's 1800 Ideen fragment 150: "One can neither explain nor comprehend the universe-one can only intuit and reveal it." ${ }^{20}$ Passages such as these offer preliminary evidence-against many recent critics - that even in 1800 Schlegel had not entirely repudiated Fichte's philosophy.

\section{Intuition as a Philosophical Problem: Fichte, Hegel, Schlegel}

To begin to appreciate Schlegel's complex stance toward intuition and intellectual intuition we will need a basic understanding of the philosophical heritage of these categories. One of the primary motivations of Fichte's philosophy-in particular, in the texts collectively known as his later Jena Wissenschaftslehre-is to establish the precise nature and status of self-consciousness. ${ }^{21}$ As a starting point, Fichte indulges in a thought experiment that he believes can reveal the unique status of self-consciousness:

I am conscious of an object B, but I cannot be conscious of $B$ without being conscious of myself. ... I am, however, only conscious of myself in that I am conscious of consciousness. I must therefore be conscious of ... the consciousness of consciousness. How will I become conscious of this consciousness? This process proceeds into infinity, and in this way consciousness cannot be explained. The main reason for this impossibility is that consciousness is always taken as a state of mind, as an object, which always requires another subject. ${ }^{22}$

So long as self-consciousness is understood as being aware of oneself as object, there seems no way to avoid an infinite regress: since every object requires a subject that is aware of the object, self-consciousness itself becomes the object of a higher-order self-consciousness, ad infinitum. The only way to avoid this problem of infinite regress, Fichte goes on to argue, is to conceive self-consciousness as the "immediate" ("unmittelbar") - that is, nondiscursiveconsciousness of the unity of subject and object (Wissenschaftslehre 30).

In his 1797 Introductions to the Wissenschaftslehre, Fichte characterizes this immediate consciousness as the "fact-act" ("Tathandlung") by which "the primordial self” (“das ursprüngliche Ich") comes into existence (Introductions 48; Zur theoretischen Philosophie 465). In a decisive move, Fichte identifies this immediate consciousness with none other than intellectual intuition: "This intuiting of himself that is ascribed to the philosopher, in performing the act whereby the self arises for him, I call intellectual intuition." ${ }^{23}$ For Fichte, we might say, the primordial Ich itself emerges in - and as - an act of intellectual intuition through which the immediate unity of subject and object is directly registered. Fichte soon goes on to affirm that "intellectual intuition is the only firm standpoint for all philosophy." 24

But what, more concretely, does Fichte mean by intellectual intuition? At various points in his work, Fichte seems to vacillate between what might be called logical and phenomenological accounts of intellectual intuition. ${ }^{25}$ On the one hand, Fichte insists that since intellectual intuition is the condition of possibility of all empirical consciousness, intellectual intuition itself is never present in 
consciousness (Introductions 9; Zur theoretischen Philosophie 425). As he puts it, "[T]here is no immediate, isolated consciousness of intellectual intuition." ${ }^{26}$ On the other hand, Fichte sometimes suggests that intellectual intuition is "demonstrable in consciousness" (“im Bewußtseyn nachzuweisen”) and hence phenomenologically verifiable (Introductions 14; Zur theoretischen Philosophie 428). In this vein, he claims that the "faculty of intellectual intuition" is something that "everyone must find immediately in himself; otherwise, he will never make its acquaintance." ${ }^{27}$

In his 1807 Phenomenology of Spirit, Hegel subjects to radical critique the foundationalist intuitionism espoused by Fichte, among others. First, he attacks intuition's nonconceptual immediacy: the content of intuition is doomed to be vacuous, Hegel argues, so long as it excludes conceptual mediation. The "rapturous haziness" ("Begeisterung und Trübheit") of intuition is a mere "empty depth" ("eine leere Tiefe"), "an intensity without content" ("eine gehaltlose Intensität"; Phenomenology 4; Phänomenologie 17). Second, Hegel claims that the radically subjective category of intuition can never serve as the objective basis for philosophy. Intuition, as Hegel puts it, "merely gives free rein both to the contingency of the content within it, and to its own caprice." 28 Third, in the introduction to Phenomenology, Hegel interrogates foundationalism itself-the very urge to "ground" philosophy on some purportedly absolute principle or assertion. Philosophy must not be grounded on a "bare assurance" since "one bare assurance is worth just as much as another." 29 All foundationalist philosophizing remains haunted by the possibility that its supposedly presuppositionless starting point in fact smuggles in a host of presuppositions that escape interrogation. On Hegel's account, instead of starting with some absolute ground, philosophy must be "an exposition of how knowledge makes its appearance" ("die Darstellung des erscheinenden Wissens"; Phenomenology 49; Phänomenologie 72). So if
Fichte's philosophy begins with the immediacy of intuition, Hegel's "phenomenology of spirit" begins with mediation and ends with an immediacy earned through mediation.

This background should help us avoid reductive accounts of Schlegel's complex stance toward the Fichtean category of intellectual intuition and should set into relief Schlegel's distinctive engagement with post-Kantian idealism more generally. In "The Concept of Irony," de Man offers a problematic account of Schlegel's agon with Fichte in large part because he fails to honor the complexity of Fichte's and Schlegel's philosophical positions. According to de Man, Fichte's radical insight is that the self is a "linguistic" construct rather than an "experiential" or "phenomenological" category (172-73). De Man then argues that Fichte's entire dialectic of the self turns out to be an "allegory of tropes"-a systematic narrative of the circulation of rhetorical tropes as they compose and decompose the linguistic self (176-77). However, de Man is only able to sustain this allegorical interpretation by ignoring both Fichte's key category of intellectual intuition and Fichte's repeated insistence that the absolute Ich is more than a linguistic construct since-as we have seen-it serves as the ontological condition of possibility of all consciousness.

Schlegel accepts the strictly linguistic status of the self, de Man goes on to argue, but rejects Fichte's move of inscribing this linguistic self within a grand narrative. Schlegelian irony, as de Man puts it, is the "necessary undoing" of Fichte's allegory of tropes (179). Tellingly, however, de Man ignores Schlegel's philosophical lectures, which suggest a more vexed stance toward Fichte than de Man allows. Two of Schlegel's lecture courses (neither of which has been translated into English) are particularly relevant for our purposes: his course Transcendental Philosophy offered at the University of Jena between 1800 and 1801 (at least part of which Hegel attended) ${ }^{30}$ and his course The Development of Philosophy 
in Twelve Books delivered to a private audience in Köln between 1804 and 1805. ${ }^{31}$ These lecture courses place Schlegel somewhere between Fichte and Hegel. Schlegel advances trenchant criticisms of intuition years before Hegel's Phenomenology appears, yet he never seems willing-or able-to take the Hegelian step of repudiating the category altogether.

Early in the Jena lectures, Schlegel registers skepticism about the faculty of intuition: "The longing for the infinite must always be a longing. It cannot occur in the form of intuition. The ideal can never be intuited. The ideal is produced through speculation." ${ }^{32}$ What seems a straightforward dismissal of the category of Anschauung, however, soon proves more complicated. Before long, he advances intellectual intuition as nothing less than the absolute basis of his philosophical system: "The consolidation of the entire primordial consciousness, when it comes into consciousness - that is, the primordial consciousness intuited and understood-is intellectual intuition. The absolute thesis of all philosophy cannot be proved; it has absolutely nothing to do with proof; it contains its proof within itself." ${ }^{33}$ Schlegel clearly subscribes here to Fichte's foundationalist intuitionism in establishing intellectual intuition as the absolute thesis of all philosophy. However, this passage also reveals some of the subtle ways in which Schlegel implicitly reworks Fichte's doctrine of intellectual intuition. While Fichte himself vacillates between conceiving intellectual intuition as a state of empirical consciousness and as the logical condition of possibility of empirical consciousness, Schlegel claims that intellectual intuition is the coming to consciousness of primordial consciousness. And whereas Fichte rarely appeals to direct selfevidence in his justification of intellectual intuition, Schlegel insists that intellectual intuition contains its proof within itself.

The Köln lectures delivered a few years later reveal an even more conflicted stance toward intuition. In contrast to the Jena lec- tures, they generally lack any talk of intellectual intuition. Schlegel here singles out for criticism the mystical epistemological basis of intuition: its source of cognition is "a supernatural, higher revelation" ("eine übernaturliche, höhere Offenbarung"; Philosophische Vorlesungen 258). Yet at this early point in the Köln lectures he still seems convinced that the category of intuition can be retained so long as its epistemological basis is revamped. He first proposes what he calls Selbstanschauung: "the investigation of all sources of philosophy leads us to self-intuition as the most certain starting point of philosophy." ${ }^{4}$

However, Schlegel's confidence in the category of Selbstanschauung wanes as he begins to generate powerful general objections to the notion of Anschauung. Recall that Fichte appeals to the category of intellectual intuition as a means of avoiding the infinite regress involved in any attempt to conceive self-consciousness as an object. Here Schlegel cleverly turns this argument implicitly against Fichte by arguing that intuition turns out to fall prey to the very infinite regress that it is meant to overcome: "This capacity to be the 'I' of 'I' is, however, infinite; for just as there is an intuition of intuition, there can just as well be an intuition of intuition of intuition and so on into infinity; this has absolutely no limits." ${ }^{\text {35 }}$ Shortly thereafter, Schlegel argues that any model of Anschauung faces the insuperable problem that fixing an object intuitively is tantamount to destroying it. "As for intuition," he writes, "it has already adequately been shown that it can afford no cognition in the actual sense precisely because it crushes the inner essence of the object-the living, the free and moving." ${ }^{36}$ For Schlegel, any theory of intuition faces a Heisenbergian dilemma: in the very process of delimiting an object as an object, intuition necessarily falsifies it. Anticipating Hegel's critique of Anschauung as an "intensity without content," Schlegel concludes that intuition "can afford no cognition in the actual sense." 
The force of these objections compels him to renounce his earlier espousal of the category of self-intuition as the basis for philosophy. He turns instead to the category of "feeling" ("Gefühl"), yet he soon admits that feeling could just as well be called "spiritual intuition" ("geistige Anschauung") or "aesthetic intuition" (“ästhetische Anschauung”; Philosophische Vorlesungen 355). Evidently, despite his uneasiness about intuition, Schlegel nonetheless feels compelled to invoke the category because he insists on grounding his philosophical system in a nonconceptual form of cognition. Hence, Benjamin aptly characterizes Schlegel's seemingly paradoxical enterprise as the search for "an unintuitable intuition" ("eine unanschauliche Intuition"; Der Begriff 42). ${ }^{37}$

Schlegel's self-defeating efforts to theorize a nonintuitional model of immediate cognition culminates in this astonishing claim: "The infinite fullness as such cannot be intuited; one must then assume an intuition that can never be completed. This concept comes only ... through the foreboding, prophesying feeling in human consciousness." ${ }^{38}$ If the infinite fullness cannot be intuited, why must we then assume such an incomplete intuition, such a mysterious faculty of prophecy? Why not rather repudiate the category of intuition altogether, as Hegel does? Over the course of his Jena and Köln lectures, as we have seen, the category of intuition reemerges in various terminological guises. Ultimately, Schlegel remains committed to an aporetic epistemology doomed to collapse repeatedly into the very intuitionism it seeks so desperately to overcome.

\section{Recuperating Hegel's Metacritique of Schlegel}

We can turn now to Hegel's critique of Schlegel's theory of irony. The standard dismissal of Hegel's critique is based on two premises. First, critics claim that Hegel's seemingly straightforward attribution of Fichtean subjec- tivism to the theory of irony fails to honor the actual complexities of Schlegel's engagement with Fichte. Second, they argue that Hegel's exclusive emphasis on a single aspect of irony at the expense of other equally fundamental aspects betrays an impoverished understanding of Schlegel's theory. Indeed, there seems no dearth of evidence to support either of these claims. Critics frequently point to Hegel's treatment of Schlegelian irony in a passage in his Lectures on the History of Philosophy:

This [Schlegel's] irony is an application of Fichte's philosophy, it emerges from Fichte's philosophy. ... It is when subjective consciousness is finished with all things: "It is I who through my cultured thoughts can negate all determinations of right, morality, good, etc.; and I know that if anything seems good to me I can just as well subvert it. I know myself absolutely as the master of all these determinations-I can make them valid or also not; all things are only true to me insofar as they please me now."39

Beginning with the vague assertion that Schlegel's theory of irony emerges from Fichte's philosophy, Hegel proceeds to lampoon the ironic consciousness as an absolute subjectivity confident in its mastery over all its determinations.

Scattered passages throughout Hegel's work echo these sentiments, inviting critics to dismiss his understanding of Romantic irony as hopelessly one-sided. Behler's response to Hegel's critique of irony is typical:

One can say that it is precisely at this point that Hegel's understanding of irony errs completely and his conception of the absolute power of the ironic self proves definitely false. For the critique that expresses itself in irony is no outwardly directed irony that merely wants to deceive and bewilder but a selfcritique of the artist directed toward himself ("self-destruction"), which should protect him from investing too much trust, hubris, and self-importance in "self-creation." ${ }^{40}$ 
Recall from the first section of this essay that Schlegel's theory of irony involves three basic coordinates: the two first-order ironies of self-creation and self-destruction and the second-order irony of irony, which alternates between self-creation and self-destruction. Working from this schema, Behler swiftly dispenses with Hegel's critique of irony. On Behler's account, Hegel mistakes the irony of self-creation for Schlegelian irony tout court, thereby neglecting-or perhaps willfully ignoring - the equally important moment of self-destruction within irony. ${ }^{41}$

I hope to demonstrate, however, that $\mathrm{He}$ gel's understanding of Schlegel's theory of irony and its allegedly Fichtean underpinnings is significantly more nuanced and penetrating than critics have been willing to acknowledge. The first step in making my case is to establish that Hegel was in fact fully aware of the complexities of Schlegel's engagement with Fichte. It has already been noted that Hegel attended at least some of Schlegel's Jena lectures, which reveal Schlegel's vexed stance toward Fichte. That Hegel did not take Schlegel to be a straightforward Fichtean is also clear from a remark in his Aesthetics: "Friedrich von Schlegel, like Schelling, started out from the Fichtean standpoint, Schelling to go beyond it entirely, Friedrich von Schlegel to develop it in his own way and to tear himself away from it." 42 Recent critics have been so eager to show the various ways Schlegel moves beyond Fichte that they tend to neglect those aspects of Schlegel's thinking that remain persistently Fichtean: most notably, as I have tried to show, his stance toward intuition. Hegel proves here to be a subtler critic of Schlegel in his careful distinction between a complete overcoming of Fichte's philosophy and a more immanentand tortured-negotiation with it. Indeed, as a characterization of Schlegel's engagement with Fichtean intuition, Hegel's remark can hardly be bettered: Schlegel tries precisely to develop the category of intuition "in his own way and to tear himself away from it."
In fact, in the short section of his Lectures on the History of Philosophy devoted to Schlegel, Hegel specifically isolates Schlegel's problematic attempt to develop forms of sensation that could avoid Fichtean subjectivism: "The Fichtean standpoint of subjectivity has retained its character of being unphilosophically worked out, and arrived at its completion in forms belonging to sensation which were in part the effort-futile though it wasto get beyond subjectivity." ${ }^{43}$ Hegel then gets quite canny. He implicitly links the Fichtean subjectivism at the core of Schlegel's theory of irony to the specifically intuitional subjectivism of Friedrich Schleiermacher. ${ }^{44}$ In his 1799 work On Religion, Schleiermacher-himself an occasional contributor to the Athenaeumrepeatedly privileges the faculty of intuition (Anschauung) as the primary means for the direct apprehension of God. ${ }^{45}$ That Schlegel and fellow early Romantics frequently praised On Religion in the Athenaeum was not lost on Hegel. So Hegel proceeds to launch a joint attack on what he perceives to be the shared intuitional basis of Schlegel's theory of irony and Schleiermacher's epistemology:

In accordance with this principle, the spiritual living essence has then transformed into self-consciousness, and it intends to know the unity of spirit immediately from itself, and in this immediacy to know it in a poetic or at least a prophetic manner. As regards the poetic manner, it knows the life and person of the Absolute immediately in an intuition, not in the Concept, and it thinks it would lose the Whole as Whole, as a self-penetrating unity, were it not to express the same in poetic form; and what it thus expressed poetically is the intuition of the personal life of selfconsciousness. - But the truth is absolute movement. ... ${ }^{46}$

Indeed, the details of this passage suggest Schlegel as the primary target. In his allusions to knowing the unity of spirit "in a poetic or at least a prophetic manner," Hegel 
registers an acute awareness of Schlegel's various efforts to theorize a nonintuitional mode of cognition-including Schlegel's last-ditch attempt to develop the category of prophecy in the Köln lectures. In his reference to intuiting the Whole as Whole, Hegel may even have in mind Schlegel's Athenaeum definition of irony as the "intuition of the Whole." Hegel's point is that all of Schlegel's efforts to overcome intuitionism are doomed to fail so long as Schlegel remains committed to the dogma of immediacy (Unmittelbarkeit).

In a dense passage in his essay "Solger's Posthumous Writings and Correspondence," Hegel most decisively links his critique of Fichtean intuition to his critique of Schlegel's theory of irony. He begins by rehearsing, in condensed form, his critique of Fichte's intuitional epistemology. He credits Fichte for bringing to consciousness "the highest starting point for the problem of philosophy" namely, the task of developing "the particular from the presuppositionless, the universal." 48 However, the principle Fichte invokes to carry out this task is "itself a presupposition" ("selbst eine Voraussetzung”; Berliner Schriften 254). It is at this point that he specifically targets Fichte's intuitional epistemology, one that is shown to underwrite Schlegel's theory of irony:

A principle must also be proved, not require that it be accepted from intuition, immediate certainty, inner revelation, or as one may call it in a word, in good faith; the requirement of proof, however, has become something obsolete for the many monochromatic philosophies of the time.... In this cited form such negativity has remained only in the one-sided, finite affirmation that it has as $I$. In this merely subjective affirmation, it has been taken up from Fichtean philosophy by Friedrich von Schlegel with a lack of understanding of the speculative and a setting aside of the same; and it has been so torn from the field of thought that, applied directly to reality, it has flourished into irony, into the negation of the liveliness of reason and truth and the debasement of the same to appearance in the subject and to appearing for others. ${ }^{49}$

What should not be missed is Hegel's careful distinction between Fichte's genuinely speculative philosophy and Schlegel's decidedly nonspeculative appropriation of Fichte. As we have seen, whereas Fichte never straightforwardly aligns intuition with immediate certainty, Schlegel makes precisely this dogmatic identification in his philosophical lectures when he claims that intellectual intuition "contains its proof within itself." For Hegel, Schlegel's assumption of the radical presuppositionlessness of his intuitional epistemology itself turns out to be an unexamined presupposition. Hegel then goes on to argue that Schlegel's merely subjective affirmation of Fichtean idealism directly sponsors his theory of irony.

In addressing Hegel's critique of Schlegel, critics have failed to acknowledge what emerges here as the strict inseparability of Hegel's critique of irony from his critique of intuition. As a result, they can easily dismiss Hegel's attribution of Fichtean subjectivism to Schlegelian irony. On my account, however, Hegel's general alignment of the ironic subject with the Fichtean subject should be taken as the corollary to his more pointed-and more fundamental-metacritique of Schlegel's theory of irony: that is, his critique of irony's underlying epistemology of intuition. The success of Hegel's metacritique of irony would then depend on the plausibility of his claim about irony's intuitional basis.

My examination of Schlegel's philosophical lectures in the previous section has, I hope, already made plausible Hegel's identification of an intuitionism at the heart of Schlegel's epistemology, so it remains to be shown how this intuitional epistemology infects Schlegel's theory of irony. Let us turn first to a revealing sentence from Hegel's discussion of Romantic irony in his Lectures on the History of Philosophy: "The divine is said to be the purely 
negative attitude, the intuition, the consciousness of the vanity of everything. . . ." ${ }^{50}$ Hegel provocatively claims here that intuition is the mode of consciousness by which the ironist registers the vanity of everything. Hegel's frequent attacks on the rhetoric of elevation pervading Schlegel's descriptions of irony then suddenly become understandable: the epistemological means by which ironists elevate themselves above everything is none other than the faculty of intuition..$^{51}$ We need only recall Schlegel's 1800 definition of irony as the "intuition of the Whole, to which we raise ourselves in an instant.” Although Schlegel rarely links irony with intuition, Hegel's point is that those occasional instances when Schlegel does establish this link betray irony's fundamental structure: ironists raise themselves to the Whole by means of the immediate perception of intuition.

In section 140 of his Elements of the Philosophy of Right, Hegel interrogates the ironist's declaration of the vanity of everything: the form of irony "is not only the vanity of all ethical content in the way of rights, duties, and laws ... but it is also the form of subjective vanity: it knows itself as the vanity of all content and in this knowledge knows itself as the Absolute." ${ }^{2}$ This passage offers us a very precise way of handling Behler's critique of Hegel. On Behler's account, Hegel treats the self-creation aspect of irony as irony tout court, thereby neglecting the equally fundamental aspect of self-destruction. However, this passage suggests that the primary target of Hegel's critique is in fact the secondorder irony hovering between the first-order ironies of self-creation and self-destruction. The passage's final clause is crucial: at precisely the moment that the ironist declares itself to be vain-the moment, we can say, of selfdestruction-it elevates itself to the status of the Absolute. What Hegel attacks, in other words, is the underlying absolute subjectivity that arrogates to itself the capacity to alternate at will between self-creation and self-destruction, between enthusiasm and skepticism.
In the fascinating oral supplement to section 140 of Elements of the Philosophy of Right-not available in either of the extant English translations of the text-Hegel traces the ironist's absolute subjectivity to an underlying Fichtean epistemology of conviction (Überzeugung):

[I]n Friedrich v. Schlegel's particular conception of the "I," this "I" is itself portrayed as God with respect to the good and beautiful, so that objective good is only a figment of my conviction and only gains support through me, and I emerge as lord and master over it and can make it disappear. Insofar as I encounter something objective, it is at the same time nugatory for me, and I therefore hover over a monstrous space, from which I call forth and destroy shapes. ${ }^{53}$

For Fichte, conviction is a prerational form of certainty, and he often claims that conviction is apodictically true: as he puts it, "conviction of error is utterly impossible." 54 Hegel's implicit suggestion is that Schlegel's theory of irony depends on a tacit identification of the Fichtean categories of intuition and conviction as a spurious means of securing intuition's apodictic validity. The ironist's self-proclaimed mastery over "the good and the beautiful" masks an absolute subjectivity for which the external world is a mere subjective projection: "objective good is only a figment" of the ironist's conviction. The brilliantly polemical final sentence targets the boundless hubris of an absolute subjectivity hovering between shapes that it alternately creates and destroys. It is no coincidence that Hegel employs here the language of hovering (schweben) - the very language Schlegel typically invokes to describe the ironist's movement between enthusiasm and skepticism. ${ }^{55}$

So if Schlegel presents his notion of irony of irony as a hovering between what seem the equally fundamental extremes of enthusiasm and skepticism, Hegel points out that such second-order hovering itself depends on a 
ground-level acceptance of enthusiasm. Let us revisit Schlegel's 1800 definition of irony as "clear consciousness of eternal agility, of the infinitely teeming chaos." Notice that Schlegel defines irony not simply as eternal agility but as the clear consciousness of eternal agility. In a Philosophische Lehrjahre fragment, as we have seen, Schlegel redefines the ironist's "clear consciousness" as the "intellectual intuition of an eternal $\chi \alpha$ [chaos]." It is as if Schlegel comes clean here in establishing the faculty of intellectual intuition as the enabling precondition for the ironist's agile hovering between enthusiasm and skepticism. From a Hegelian vantage, however, the Schlegelian ironist seems not quite agile enough, since the ironist's own intuitive faculty remains unironized. In effect, Hegel applies Schlegel's argument in the Köln lectures about the infinite regress of intuition to the intuitional epistemology at the basis of Schlegel's theory of irony. Hegel's basic point is that Schlegel's invocation of intellectual intuition does not so much resolve the problem of infinite regress as mask it. If irony is the intellectual intuition of an eternal chaos, then this intuition will in turn have to become the object of a higher-order intuition, ad infinitum.

Hegel's metacritique of Schlegelian irony thus proves to be strictly immanent: it seeks to demonstrate that a problem internal to Schlegel's theory of irony-namely, the problem of infinite regress-is ultimately insuperable, and Schlegel's last-ditch recourse to intellectual intuition simply reinstates the problem in another form. For Hegel, then, Schlegelian irony turns out to be insufficiently radical in that it fails to follow through on its own inner logic. In the Jena and Köln lectures, Schlegel is unable to repudiate the category of intuition even in the face of his own strong doubts about the category. From Hegel's metaperspective, this point of equivocation in Schlegel's epistemology results in a permanently unstable theory of irony; and irony's inherent instability, in turn, attests to the fundamen- tal inadequacy-one might even say incoherence-of irony as a self-sustaining paradigm. A truly thoroughgoing irony would radicalize its own instability and thereby ironize the absolute subject (the "primordial consciousness" from the Jena lectures) that gets smuggled into Schlegel's theory of irony. As soon as this absolute subject is itself subjected to irony, irony emerges in its truth as a dialectical moment that ultimately supersedes itself-that is, as Hegel puts it in his Aesthetics, the necessary moment of "infinite absolute negativity" ("unendliche absolute Negativität"; 160; Vorlesungen über die Ästhetik 211). Ironically enough, it is Schlegel who expresses this Hegelian view of irony as a self-sublating moment years before Hegel comes on the scene. In a private notebook dated around the time of his Athenaeum contributions, Schlegel observes with startling honesty, "Perfect, absolute irony ceases to be irony and becomes serious." ${ }^{\prime 6}$

\section{Toward a Dialectical Hermeneutics}

De Man acknowledges at the outset of "The Concept of Irony" that the title of his essay "is taken from Kierkegaard, who wrote the best book on irony that's available" (163). Curiously, however, instead of specifying what makes Kierkegaard's The Concept of Irony the best contribution to discourse on irony, de Man goes on to lump Kierkegaard with Hegel and to argue that both of them are guilty of reducing irony to a moment in "a dialectics of history" (170). Why this ambiguous gesture of avowing his debt to Kierkegaard only to suppress the subtlety and force of Kierkegaard's argument? It is as if de Man opens his essay with a vague paean to Kierkegaard to excuse himself from confronting the philosophical and hermeneutic implications of Kierkegaard's distinctive recasting of the Hegel-Schlegel debate. Indeed, I hope to demonstrate that Kierkegaard's unique intervention threatens the foundations of de Man's poststructuralist hermeneutics. 
De Man is no doubt correct to claim that Kierkegaard adopts an essentially Hegelian stance toward irony. Kierkegaard clearly follows Hegel in arguing that Schlegel's theory of irony is grounded in an inflation of Fichte's Ich into what he calls "an exaggerated subjectivity, a subjectivity raised to the second power" (275). However, Kierkegaard's basic move is to recover and amplify an aspect of Hegel's critique of Schlegel that remains almost entirely submerged under Hegel's polemics (and to which I briefly alluded at the end of the previous section): namely, Hegel's favorable construal of irony as a dialectical moment of "infinite absolute negativity" (328). Kierkegaard expresses the central thesis of his dissertation in a dense aphorism that serves as this essay's epigraph: "Irony as the negative is the way; it is not the truth but the way" (327). The polemical cast of Hegel's critique of Schlegel occludes the fact that Hegel accords an important place to irony in his philosophical system by conceiving it as the fundamental moment of infinite absolute negativity. And lest we assume that this is a term of censure, we should recall that Hegel was the foremost champion of the need to "tarry with the negative." ${ }^{\text {" }}$ By insisting on irony as the way, Kierkegaard foregrounds the central role of irony in Hegel's own phenomenology of spirit and provides the resources to defend Hegelian dialectics against recent poststructuralist-inflected critiques originating in the work of Derrida.

The basis of Hegelian dialectics is the operation of Aufhebung ("sublation") as the negation of the negation. Accordingly, in such works as Of Grammatology (1967), Writing and Difference (1967), and Glas (1973), Derrida grounds his critique of Hegelian dialectics in a searching interrogation of Hegel's notion of Aufhebung. For Derrida, Hegelian Aufhebung consists in the double gesture of invoking the moment of negativity only to reinscribe this moment into a positive metaphysics of the Absolute. ${ }^{58}$ At the core of Derrida's critique, in other words, is the now familiar reproach that Hegel proves overeager to sublate the moment of negativity into his positive system, thereby failing to honor negativity as such — or what Derrida variously calls in Writing and Difference "negativity without reserve" (259), the "experience of absolute difference" (263), or "the play outside meaning" (274). Hegelian Aufhebung, as Derrida puts it, "conserves the stakes, remains master of the play, limiting it and putting it to work by giving it form and meaning" (255). ${ }^{59}$

Although this is not the occasion for an assessment of Derrida's alternative model of negativity, I can at least begin to interrogate Derrida's critique of Hegelian negativity. Tarrying with the intricacies of Hegel's critique of irony can help us appreciate that Hegel's notion of negativity is more radical and nuanced than Derrida allows. ${ }^{60}$ In Phenomenology of Spirit, Hegel vividly characterizes his dialectical enterprise as "the way of despair" ("Weg der Verzweiflung”; 49; Phänomenologie 72). Kierkegaard, in effect, builds irony into the core of Hegelian dialectics by conceiving the way of despair as none other than the way of irony itself-that is, the way of infinite absolute negativity. From a Kierkegaardian perspective, what Derrida's critique misses is precisely the absoluteness of Hegel's moment of infinite absolute negativity. As Hegel's critique of irony demonstrates, the absolutization of negativity means nothing less than pursuing the immanent logic of a given stance to the point where that stance is forced to declare its internal impossibility and thereby to call for its own self-sublation. ${ }^{61}$ Accordingly, Hegelian Aufhebung is the negation of the negation not in the sense of negating the negative into a positive but in the sense of absolutizingor radicalizing - the negative itself. Dialectics, as Hegel puts it, is a "self-completing skepticism" ("sich vollbringende Skeptizismus"), a skepticism so radical that it dissolves the skeptical paradigm from within (Phenomenology 50; Phänomenologie 72).

De Man's dismissal of Hegel's and Kierkegaard's dialectical approach to irony and his 
selective reading of Schlegel's theory of irony thus prove to be inseparable from a Derridean orientation that forces him to overlook or suppress many of the complexities involved in Hegelian dialectics. The stakes of de Man's interpretation of Schlegel become apparent in "The Concept of Irony" when de Man goes on to derive a poststructuralist hermeneutics based on the endless "free play of the signifier" (181). For de Man, textuality is a form of permanent parabasis: the semantic indeterminacy of the literary text permanently frustrates the reader's will to interpretive mastery. De Man's key move is to shift the locus of agency from the reader to the text. As he puts it, "Words have a way of saying things which are not at all what you want them to say" (181). Starting from this premise, de Man draws the now familiar implications of a poststructuralist hermeneutics: in confronting a text, the reader is faced with an uncontrollable "polysemy of meanings" and the text becomes endless and playful testimony to "the impossibility of understanding" (167).

From a Hegelian vantage, however, we can ask, What if de Man's very reveling in the text's refusal of understanding masks a more fundamental will to interpretive mastery that goes unironized? Notice that although de Man grants the text enough agency to frustrate the reader's desire for semantic stability, he nonetheless retains just enough readerly agency to detect-and to savor-the text's ironic polysemy. De Man's poststructuralist hermeneutics, in other words, betrays an abortive radicality in its constitutive incapacity to ironize the stable readerly standpoint from which to revel in the endless free play of the signifier. ${ }^{62}$ Indeed, one could probe even further and show that beneath the de Manian reader's reveling in the text's ironic free play lurks an absolute commitment to a discursive orientation to texts, one grounded in the assumption that reading a text is primarily an effort to establish what the text says or means. For de Man, as we have seen, words may say things that the reader does not want them to say, but what go unquestioned are the reader's narrowly semantic expectations in the first place. ${ }^{63}$

What would happen, we might ask, if de Man granted the text the power to call into question even these ground-level readerly expectations? In the brilliant final section of The Concept of Irony (tellingly entitled "Irony as a Controlled Element, the Truth of Irony"), Kierkegaard explores this possibility by sketching a hermeneutics-derived from his recasting of Hegel's critique of Schlegel-that can be read as a powerful proleptic challenge to de Manian poststructuralism. Kierkegaard's decisive move is to follow through on de Man's abortive attempt to shift the locus of agency from the reader to the text: hence, for Kierkegaard, "the poem has the center of gravity in itself" (324). Adapting the Hegelian view of irony to the hermeneutic sphere, Kierkegaard conceives the literary text as a dialectical arena in which the pressures of irony are continually negotiated. As Kierkegaard puts it, "[I]rony is not present at some particular point of the poem but is omnipresent in it, so that the irony visible in the poem is in turn ironically controlled" (324). In startling anticipation of twentieth-century modernism, Kierkegaard suggests that irony can be a controlled element in a text precisely in the text's reflexive capacity to adopt an ironic stance toward its own ironic energies. Hence, from a Kierkegaardian perspective, the text might be able to ironize the very de Manian impulse to read texts in terms of the endlessly ironic free play of the signifier.

Kierkegaard would have been the first to insist on the limitations of abstract thinking about art, so I propose that we turn to a brief example from modernist poetry to enliven these abstractions. ${ }^{64}$ In the opening lines of Wallace Stevens's poem "Man Carrying Thing" (1947), the speaker stages the poem as the dynamic site of an active textual agency capable at once of reflecting on and dictating the terms in which it is read: 
The poem must resist the intelligence

Almost successfully.

Notice first the speaker's acute reflexive awareness of the de Manian temptation to read poetry as a permanent parabasis of the reader's intelligence - that is, as a permanent frustration of the reader's impulse to understand the text at the semantic level. In fact, taken by itself, the first line would give succinct expression to an essentially ironic imperative: "The poem must resist the intelligence." But how would de Man handle the second line? How, in other words, would de Man account for a poetic intelligence so supple and so canny in the deployment of its reflexive energies that it can adopt an ironic stance toward the ironic imperative itself? Everything depends on the delicate-and, indeed, richly ironicprecision of the "almost." It is in the dialectical space of this "almost" that the speaker at once registers and resists the temptation to reduce the intricate art of reading a poem to the question of whether the poem caters to or resists the reader's "intelligence." And it is in the space of this "almost" that one could begin to challenge any hermeneutic orientation that conceives the stakes of reading a text in primarily discursive terms.

The absolute Ich at the basis of Schlegel's theory of irony, we might say, finds its contemporary hermeneutic analogue in the permanently suspicious reader grown leery of traditional claims to aesthetic value and for whom the literary text is a cultural document that reflects - or, at best, reflects on - the complex sociocultural field in which it is embedded. If the poststructuralist critic tends to reduce the semantic dimension of literary texts to an endless proliferation of discursive signifiers, the cultural-studies-oriented critic tends to epiphenomenalize the semantic features of texts into so many elements in an elaborate sociological symptomatology. Both interpretive approaches, in other words, rely on a severely impoverished model of what counts as semantic: their shared adoption of an a priori negative stance toward the work of art reflects an underlying hermeneutics of suspicion that remains constitutively blind to what Theodor Adorno, in a decidedly Hegelian vein, calls the "force of negativity in the artwork" itself. ${ }^{65}$

Importing Hegel's dialectical model of irony as infinite absolute negativity into the hermeneutic sphere would mean drastically widening the scope of textual negativity. A dialectical alternative to the hermeneutics of suspicion dominating contemporary literary studies would be a hermeneutics that genuinely risks shifting the center of gravity from the reader to the text-in other words, a hermeneutics that strives to honor the text's immanent forces of negativity. Instead of contouring passively to the reader's given hermeneutic orientation, the text would be able to shape the very terms of the reader's groundlevel engagement with it. By rendering fluid the reader's normally fixed semantic expectations, the text's negative energies could expand and enrich the reader's hermeneutic grammar for determining what counts as semantically salient in the first place. Capable of turning its suspicion against the suspicious readerly stance itself, the text would constitute a dialectical locus where we could inhabit and explore modes of being that simply cannot be accounted for in the terms of sociocultural critique.

Perhaps only a dialectical hermeneutics can leave us open to the radical possibility that such claims about the potentialities of art cannot be straightforwardly dismissed as hopeless piety or ideological fantasy. In an all too ironic age, one could do worse than to seek to activate those traces of spirit that threaten to be ironized away.

\section{Notes}

1. "Ironie er som det Negative Veien; ikke Sandheden, men Veien” (327; Om Begrebet Ironi 329). 
2. "Die Ironie ist eine permanente Parekbase" (Philosophische Lehrjahre 85). All unattributed translations of German passages are my own, and I often silently emend attributed translations.

3. In "The Politics of Permanent Parabasis," Michel Chaouli offers a helpful discussion of Schlegel's understanding of parabasis.

4. "Welche Götter werden uns von allen diesen Ironien erretten können?" (Charakteristiken 369). A translation of Schlegel's “Über die Unverständlichkeit," titled "On Incomprehensibility," can be found in his Lucinde and the Fragments.

5. In their early work, Benjamin and Lukács follow Kierkegaard in acknowledging the power not only of Schlegel's theory of irony but also (if only implicitly) of Hegel's critique of it. See Lukács's Die Theorie 73 and Benjamin's Der Begriff 75-81.

6. "Ein ganz Großer, Hegel, sagt aus blindem $\mathrm{Ha} \beta$ Falsches über F. Schlegels romantische Ironie" (50). For similar verdicts, see Allemann 97; StrohschneiderKohrs 216; Behler, Studien 19; Bubner, "Zur dialektischen Bedeutung" 93-94; Bohrer 146; and Egginton 1040. One of the few critics to offer a more sympathetic view of Hegel's critique is Otto Pöggeler in his study Hegels Kritik der Romantik (45-54), but he remains at the general level of establishing irony as "substanceless subjectivity" ("substanzlose Subjektivität"). The most comprehensive treatment of Hegel's critique of Schlegelian irony is Behler's long chapter "Hegels Polemiken gegen Ironie" (Ironie 115-49), but Behler also dismisses Hegel's critique (126).

7. Frank might be the most vocal and influential critic arguing for Schlegel's more or less total break with Fichte. See lecture 17 of Einführung (287-306); "Philosophische Grundlagen" 106-30, and lectures 10 and 11 of Philosophical Foundations (177-200). Also see Bubner, "Von Fichte zu Schlegel"; Behler, German Romantic Literary Theory 184-94; Rush 187; ch. 7 of Beiser (106-30); Millán-Zaibert; Götze; and Frischmann.

8. Similarly, Beiser claims, "If Schlegel were ever a disciple of Fichte, it was only for a short time, probably at most for a year, from the summer of 1795 to the summer of 1796 " (121).

9. Since Benjamin's sustained treatment of the problematic of intuition in Fichte and Schlegel, few critics have addressed the complexities of Schlegel's stance toward intuition. An important exception is Frischmann's helpful discussion of Schlegel's engagement with Fichtean intuition in her recent book (176-83).

10. I think one can make a more general case for the central role of the category of intuition in both German and British Romanticism. Some of the relevant source texts for such a study would be Novalis's Fichte-Studien and Samuel Taylor Coleridge's Biographia Literaria. In my article "The Specter of Hegel in Coleridge's Biographia Literaria," I argue that Coleridge's philosophical argu- ment in the Biographia undermines itself as a result of his vexed stance toward intuition.

11. For a classic survey of the various "subjective" and "objective" interpretations of Schlegel's theory of irony in the critical literature, see Immerwahr.

12. "[D]ie Stimmung, welche alles übersieht, und sich über alles Bedingte unendlich erhebt, auch über eigne Kunst, Tugend, oder Genialität” (Charakteristiken 152). See Schlegel's Philosophical Fragments for translations of the Lyceum and Athenaeum fragments.

13. "[E]in Gefühl von dem unauflöslischen Widerstreit des Unbedingten und des Bedingten" (Charakteristiken 160)

14. "[S]tete Wechsel von Selbstschöpfung und Selbstvernichtung" (Charakteristiken 172).

15. "Obgleich dieser Rhythmus von Selbstschöpfung und Selbstvernichtung, von Enthusiasmus und Skepsis das grundlegende Merkmal der von Schlegel bestimmten Ironie umrei $\beta \mathrm{t} . .$. ." (Ironie 97).

16. "Ironie ist klares Bewu $\beta$ tsein der ewigen Agilität, des unendlich vollen Chaos" (Charakteristiken 263).

17. "Ironie ist klares $\chi \alpha$ in Agilität, intell.[ektuale] Ansch.[auung] eines ewigen $\chi \alpha$..." (228).

18. "Wir halten uns also nur an die Bedeutung des Ganzen; was den Sinn, das Herz, den Verstand, die Einbildung einzeln reizt, rührt, beschäftigt und ergötzt, scheint uns nur Zeichen, Mittel zur Anschauung des Ganzen, in dem Augenblick, wo wir uns zu diesem erheben" (Charakteristiken 323).

19. For references to Anschauung and intellektuale Anschauung, see Ideen fragments 78 (263), 102 (266), and 150 (271) and Athenaeum fragments 76 (176), 102 (180), 336 (223-25), 342 (226), and 448 (254)

20. "Das Universum kann man weder erklären noch begreifen, nur anschauen und offenbaren" (Charakteristiken 271).

21. Any fully adequate account of the category of intellectual intuition would have to begin with a discussion of Kant, but for reasons of space, I skip Kant and proceed directly to Fichte.

22. "Ich bin mir irgend eines Objects B bewust, deßen aber kann ich mir nicht bewust sein, ohne mir meiner selbst bewust zu sein.... Ich bin mir aber nur dadurch meiner selbst bewust[,] da $\beta$ ich mir des Bewustseins bewust bin. Ich mu $\beta$ mir also bewust sein ... des Bewustseins vom Bewustsein. Wie werde ich mir deßen bewust? Die $\beta$ geht ins unendliche fort und auf diese Weise läßt sich das Bewustsein nicht erklären. Der Hauptgrund dieser Unmöglichkeit ist, $\mathrm{da} \beta$ das Bewustsein als Zustand des Gemüths, immer als Object genommen wurde, wozu es denn immer eines anderen Subjectes bedurfte" (Wissenschaftslehre 30).

23. "Dieses dem Philosophen angemutete Anschauen seiner selbst im Vollziehen des Aktes, wodurch ihm das Ich entsteht, nenne ich intellektuelle Anschauung" (Introductions 46; Zur theoretischen Philosophie 43). 
24. "Die intellektuelle Anschauung ist der einzige feste Standpunkt für alle Philosophie" (Introductions 46-50; Zur theoretischen Philosophie 466).

25. For helpful discussions of this aspect of Fichte's philosophy, see Neuhouser 86; Bowie 78.

26. " $[D] a \beta$ es kein unmittelbares, isoliertes Bewu $\beta \mathrm{t}$ sein der intellektuellen Anschauung gibt ...” (Introductions 47; Zur theoretischen Philosophie 464).

27. "Jeder mu $\beta$ es [ein solches Vermögen der intellektuellen Anschauung] unmittelbar in sich selbst finden, oder er wird es nie kennen lernen" (Introductions 46; Zur theoretischen Philosophie 463).

28. "[N]ur bald in sich selbst die Zufälligkeit des Inhalts, bald in ihm die eigene Willkür gewähren lä $\beta \mathrm{t}$ " (Phenomenology 6; Phänomenologie 18).

29. "[E]in trockenes Versichern gilt aber gerade soviel als ein anderes" (Phenomenology 49; Phänomenologie 71)

30. Behler cites as evidence a letter of Hegel's indicating attendance at some of Schlegel's Jena lectures (Ironie 139).

31. For a general discussion of the circumstances of Schlegel's Jena lectures, see Behler's essay, "Friedrich Schlegels Vorlesungen über Transzendentalphilosophie: Jena 1800-1801."

32. "Die Sehnsucht nach dem Unendlichen mu $\beta$ immer Sehnsucht seyn. Unter der Form der Anschauung kann es nicht vorkommen. Das Ideal lässt sich nie anschauen. Das Ideal wird durch Spekulazion erzeugt" (Philosophische Vorlesungen 8).

33. "Die Zusammenfassung des ganzen ursprünglichen Bewußtseyns, wenn es zum Bewußtseyn kommt, d. h. das ursprüngliche Bewu $\beta$ tseyn anschaut und versteht, ist die intellektuelle Anschauung. Die absolute Thesis aller Philosophie kann nicht bewiesen werden; es geht schlechthin nichts darüber; es enthält seinen Beweis in sich selbst" (Philosophische Vorlesungen 24).

34. "[D]ie Untersuchung aller Quellen der Philosophie führt uns auf die Selbstanschauung, als den sichersten Anfangspunkt der Philosophie" (Philosophische Vorlesungen 299).

35. "Diese Fähigkeit, das Ich des Ichs zu sein, ist aber unendlich; denn so wie es eine Anschauung der Anschauung gibt, kann es ebensogut eine Anschauung der Anschauung der Anschauung geben usw. bis ins unendliche; dies hat gar keine Grenzen” (Philosophische Vorlesungen 325).

36. "Was die Anschauung betrifft, so ist schon hinlänglich dargetan worden, $\mathrm{da} \beta$ sie im eigentlichen Sinne keine Erkenntnis geben kann, weil sie eben das innere Wesen des Gegenstandes, das Leben, das Freie und Bewegliche erdrückt" (Philosophische Vorlesungen 331).

37. The English translation of Benjamin's text misleadingly renders "unanschauliche Intuition" as "noneidetic intuition" (“Concept” 139-40).

38. "Die unendliche Fülle als solche läßt sich nicht anschauen, man müßte dann eine Anschauung annehmen, die nie vollendet werden könnte. Dieser Begriff kommt nur
... durch das ahnende, weissagende Gefühl in das menschliche Bewußtsein" (Philosophische Vorlesungen 381).

39. "Diese Ironie ist eine Wendung der Fichteschen Philosophie, aus ihr hervorgegangen.... Sie ist das Fertigsein des subjektiven Bewußtseins mit allen Dingen: »Ich bin es, der durch mein gebildetes Denken alle Bestimmungen zunichte machen kann, Bestimmungen von Recht, Sittlichkeit, Gut usw.; und ich wei $\beta$, dass, wenn mir etwas als gut erscheint, gilt, ich mir dies ebenso auch verkehren kann. Ich wei $\beta$ mich schlechthin als den Herrn über all diese Bestimmungen, kann sie gelten lassen und auch nicht; alles gilt mir nur wahr, insofern es mir jetzt gefällt"” (Greek Philosophy 400-01; Vorlesungen ... I 460).

40. "Man kann sagen, da $\beta$ genau an dieser Stelle das Ironieverständnis Hegels völlig in die Irre geht und natürlich schon seine Sehweise der absoluten Vollmacht des ironischen Ich falsch ist. Denn die Kritik, die sich in der Ironie äußert, ist keine nach außen gerichtete Ironie, die blo $\beta$ täuschen und verblüffen will, sondern eine auf sich selbst gerichtete Selbstkritik des Künstlers ('Selbstvernichtung'), die ihn davor schützen soll, zu viel Vertrauen, Anmaßung und Selbsteinschätzung in die 'Selbstschöpfung' zu investieren” (Ironie 126).

41. Benjamin was one of the first commentators to emphasize the moment of objectivity in Schlegel's theory of irony ("Concept" 160-65; Der Begriff 75-81). See also Strohschneider-Kohrs 216 and Bohrer 147.

42. "Friedrich von Schlegel wie Schelling gingen von dem Fichteschen Standpunkt aus, Schelling, um ihn durchaus zu überschreiten, Friedrich von Schlegel, um ihn eigentümlich auszubilden und sich ihm zu entreißen" (Aesthetics 64; Vorlesungen über die Ästhetik 93).

43. "Der Fichtesche Standpunkt der Subjektivität hat seine nicht philosophisch ausgeführte Wendung behalten und so seine Vollendung erhalten in Formen, die der Empfindung angehören und zum Teil das Bestreben waren, über die Subjektivität hinauszugehen, obgleich es dazu unfähig war" (Medieval and Modern Philosophy 507; Vorlesungen ... III 415).

44. For a helpful account of Schleiermacher's theological doctrine and Hegel's critique of it, see Reid.

45. For instance, Schleiermacher calls the "intuition of the universe" ("Anschauen des Universums") "the highest and most universal formula of religion" ("die allgemeinste und höchste Formel der Religion”) (24; Über die Religion 52).

46. "Nach diesem Prinzip hat denn das geistige lebendige Wesen sich in das Selbstbewu $\beta$ tsein versetzt, und die Einheit des Geistes meint es unmittelbar aus sich selbst und in dieser Unmittelbarkeit auf eine poetische oder wenigstens prophetische Weise zu wissen. Was die poetische Weise betrifft, so wei $\beta$ sie von Leben und Person des Absoluten unmittelbar in einer Anschauung, nicht im Begriffe, und meint das Ganze als Ganzes, als sich durchdringende Einheit zu verlieren, wenn sie es nicht poetisch ausspräche; und was sie poetisch ausspricht, ist die Anschauung 
des eigenen Lebens seines Selbstbewußtseins. - Aber die Wahrheit ist die absolute Bewegung..." (Medieval and Modern Philosophy 508-09; Vorlesungen ... III 416).

47. "[D]er höchste Anfangspunkt für das Problem der Philosophie" (Berliner Schriften 254).

48. " $[\mathrm{V}]$ on dem Voraussetzungslosen, Allgemeinen aus das Besondere zu entwickeln" (Berliner Schriften 254).

49. "Ein Prinzip muß auch bewiesen, nicht gefordert werden, daß es aus Anschauung, unmittelbarer Gewißheit, innerer Offenbarung, oder wie man es nennen mag, mit einem Wort auf Treu und Glauben angenommen werde; die Forderung des Beweisens ist aber für die so vielen und zugleich so eingeworden. ... In der angeführten Form ist jene Negativität nur in der einseitigen, endlichen Affirmation geblieben, welche sie als Ich hat. In dieser nur subjektiven Affirmation ist sie aus der Fichteschen Philosophie mit Unverständnis des Spekulativen und Beiseitesetzung desselben von Friedrich von Schlegel aufgenommen und aus dem Gebiete des Denkens so herausgerissen worden, daß sie, direkt auf die Wirklichkeit gewendet, zur Ironie gediehen ist, zum Verneinen der Lebendigkeit der Vernunft und Wahrheit und zur Herabsetzung derselben zum Schein im Subjekt und zum Scheinen für andere" (Berliner Schriften 255).

50. "Das Göttliche soll die negative Haltung sein, das Anschauen, Bewußtsein der Eitelkeit von allem ..." (Greek Philosophy 401; Vorlesungen... I 461).

51. Irony, as Hegel tersely puts it, is always "away above everything" ("über alles hinaus") (Aesthetics 243; Vorlesungen über die Ästhetik 315).

52. "Diese Gestalt ist nicht nur die Eitelkeit alles sittlichen Inhalts der Rechte, Pflichten, Gesetze ... sondern sie tut auch die Form, die subjektive Eitelkeit, hinzu, sich selbst als diese Eitelkeit alles Inhalts zu wissen und in diesem Wissen sich als das Absolute zu wissen" (Elements 182; Grundlinien 279).

53. "Von Fichte ist eigentlich nicht zu sagen, dass er im Praktischen die Willkür des Subjekts zum Prinzip gemacht habe, aber späterhin ist im Sinne der besonderen Ichheit von Friedrich v. Schlegel dieses Besondere selbst in betreff des Guten und Schönen als Gott aufgestellt worden, so da $\beta$ das objektiv Gute nur ein Gebilde meiner Überzeugung sei, nur durch mich einen Halt bekommt, und da $\beta$ ich es als Herr und Meister hervortreten und verschwinden lassen kann. Indem ich mich zu etwas $\mathrm{Ob}-$ jektivem verhalte, ist es zugleich für mich untergegangen, und so schwebe ich über einem ungeheuren Raume Gestalten hervorrufend und zerstörend" (Grundlinien 286).

54. "Überzeugung vom Irrtum ist schlechterdings unmöglich" (Introductions 98; Zur theoretischen Philosophie 513).

55. See, for instance, Schlegel's invocation of schweben in Athenaeum fragment 116 (Charakteristiken 182-83).

56. "Die vollendete absolute Ironie hört auf Ironie zu seyn und wird ernsthaft" (Fragmente 144).
57. Hegel refers to the "magical power" ("Zauberkraft") of "tarrying" ("verweilen") with the negative in the preface to Phenomenology (19; Phänomenologie 36).

58. I focus here on Derrida's critique of Hegel in Writing and Difference, but he offers a similar critique in $O f$ Grammatology (106) and Glas (8-11, 25-26).

59. Trans. slightly modified. The original reads, "Par ce recours à l'Aufhebung qui conserve la mise, reste maîtresse du jeu, le limite, le travaille en lui donnant forme et sense..." (L'écriture 376).

60. For an interesting Hegelian critique of Richard Rorty's poststructuralist-inflected theory of liberal ironism, see Matarrese.

61. Robert Pippin offers an illuminating account of Hegel's notion of "absolute negativity" (163).

62. For a similar argument against poststructuralist models of irony, see Berel Lang's shrewd essay "The Limits of Irony," which convincingly argues that poststructuralist irony-like its Romantic predecessor-ultimately "discloses a transcendent and foundationalist origin” (580).

63. A longer essay would have to address in detail de Man's brilliant earlier treatment of irony in his 1969 essay "The Rhetoric of Temporality" (contained in Blindness and Insight). In "The Rhetoric of Temporality," de Man starts out with a diachronic account of irony as "unrelieved vertige, dizziness to the point of madness" (215), but by the end of the essay he claims that irony betrays an ultimately "synchronic structure" in its reliance on an epistemology of the "instant" (226). I would suggest that the early de Man's insight bears striking affinities with Hegel's critique of Schlegel: Schlegel's apparently diachronic conception of irony as "permanent parabasis" proves inseparable from his appeal to a synchronic epistemology of intuition. "The Rhetoric of Temporality" could then be read as an uncanny proleptic critique of his later essay "The Concept of Irony."

64. For a more sustained treatment of the problematic of irony in twentieth-century American poetry, see my articles on Wallace Stevens and John Ashbery, where I argue that both writers seek to develop a poetics that resists the seductions of the ironic stance ("From Deconstruction"; "Postmodern Convexity").

65. “[D]ie Kraft der Negativität im Kunstwerk” (Aesthetic Theory 12; Ästhetische Theorie 26).

\section{Works Cited}

Adorno, Theodor. Aesthetic Theory. Trans. Robert HullotKentor. Minneapolis: U of Minnesota P, 1997. Print. . Ästhetische Theorie. 1970. Frankfurt am Main: Suhrkamp, 1992. Print.

Allemann, Beda. Ironie und Dichtung. Pfullingen: Neske, 1956. Print.

Behler, Ernst. "Friedrich Schlegels Vorlesungen über Transzendentalphilosophie: Jena 1800-1801.” Der 
Streit um die Gestalt einer Ersten Philosophie. Ed. Walter Jaeschke. Hamburg: Meiner, 1999. 52-71. Print.

—. German Romantic Literary Theory. Cambridge: Cambridge UP, 1993. Print.

—. Ironie und literarische Moderne. Paderborn: Schöningh, 1997. Print.

- Studien zur Romantik und zur idealistischen Philosophie. Paderborn: Schöningh, 1988. Print.

Behler, Ernst, and Jochen Hörisch, eds. Die Aktualität der Frühromantik. Paderborn: Schöningh, 1987. Print.

Beiser, Frederick. The Romantic Imperative: The Concept of Early German Romanticism. Cambridge: Harvard UP, 2003. Print.

Benjamin, Walter. Der Begriff der Kunstkritik in der deutschen Romantik. 1916. Frankfurt am Main: Suhrkamp, 1973. Print.

"The Concept of Criticism in German Romanticism.” Trans. David Lachterman, Howard Eiland, and Ian Balfour. Selected Writings I: 1913-1926. Ed. Marcus Bullock and Michael Jennings. Cambridge: Belknap, 1996. 116-200. Print.

Bohrer, Karl Heinz. Die Kritik der Romantik. Frankfurt am Main: Suhrkamp, 1989. Print.

Bowie, Andrew. Aesthetics and Subjectivity: From Kant to Nietzsche. 2nd ed. Manchester: Manchester UP, 2003. Print.

Bubner, Rüdiger. "Von Fichte zu Schlegel." Fichtes Wissenschaftslehre 1794: Philosophische Resonanzen. Ed. Wolfram Hogrebe. Frankfurt am Main: Suhrkamp, 1995. 35-49. Print.

"Zur dialektischen Bedeutung romantischer Ironie.” Behler and Hörisch 85-95.

Chaouli, Michel. "The Politics of Permanent Parabasis." Studies in Romanticism 42.3 (2003): 323-40. Print.

de Man, Paul. “The Concept of Irony.” Aesthetic Ideology. Minneapolis: U of Minnesota P, 1996. 163-84. Print.

. "The Rhetoric of Temporality." Blindness and Insight. Minneapolis: U of Minnesota P, 1983. 187-228. Print.

Derrida, Jacques. L'écriture et la différence. Paris: Seuil, 1967. Print.

_ Glas. Trans. John P. Leavey, Jr., and Richard Rand. Lincoln: U of Nebraska P, 1984. Print.

—. Of Grammatology. Trans. Gayatri Chakravorty Spivak. Baltimore: Johns Hopkins UP, 1976. Print.

—. Writing and Difference. Trans. Alan Bass. Chicago: U of Chicago P, 1978. Print.

Egginton, William. "Cervantes, Romantic Irony and the Making of Reality." MLN 117.5 (2002): 1040-68. Print.

Fichte, Johann Gottlieb. Introductions to the Wissenschaftslehre. Trans. Daniel Breazeale. Indianapolis: Hackett, 1994. Print.

—. Wissenschaftslehre nova methodo. Hamburg: Meiner, 1982. Print.
- Zur theoretischen Philosophie. Ed. I. H. Fichte. Berlin: Veit und Comp, 1845-46. Print. Vol. 1 of Sämmtliche Werke.

Frank, Manfred. Einführung in die frühromantische Ästhetik. Frankfurt am Main: Suhrkamp, 1989. Print.

- The Philosophical Foundations of Early German Romanticism. Trans. Elizabeth Millán-Zaibert. Albany: State U of New York P, 2004. Print.

__ . "Philosophische Grundlagen der Frühromantik." Athenäum: Jahrbuch für Romantik 4 (1994): 37-130. Print.

Frischmann, Bärbel. Vom transzendentalen zum frühromantischen Idealismus. Paderborn: Schöningh, 2005. Print.

Götze, Martin. Ironie und absolute Darstellung. Paderborn: Schöningh, 2001. Print.

Hegel, G. W. F. Aesthetics: Lectures on Fine Art. Trans. T. M. Knox. Vol. 1. Oxford: Clarendon, 1975. Print.

_. Berliner Schriften 1818-1831. Frankfurt am Main: Suhrkamp, 1970. Print. Vol. 11 of Werke.

- Elements of the Philosophy of Right. Trans. H. B. Nisbet. Cambridge: Cambridge UP, 1991. Print.

—. Greek Philosophy to Plato. Trans. E. S. Haldane. Lincoln: U of Nebraska P, 1995. Print. Vol. 1 of Lectures on the History of Philosophy.

- Grundlinien der Philosophie des Rechts oder Naturrecht und Staatswissenschaft im Grundrisse. Frankfurt am Main: Suhrkamp, 1970. Print. Vol. 7 of Werke.

- Medieval and Modern Philosophy. Trans. E. S. Haldane and Frances Simson. Lincoln: U of Nebraska P, 1995. Print. Vol. 3 of Lectures on the History of Philosophy.

—. Phänomenologie des Geistes. Frankfurt am Main: Suhrkamp, 1970. Print. Vol. 3 of Werke.

-. Phenomenology of Spirit. Trans. A. V. Miller. Oxford: Oxford UP, 1977. Print.

_. Vorlesungen über die Ästhetik I. Frankfurt am Main: Suhrkamp, 1970. Print. Vol. 13 of Werke.

_. Vorlesungen über die Geschichte der Philosophie I. Frankfurt am Main: Suhrkamp, 1971. Print. Vol. 18 of Werke.

—. Vorlesungen über die Geschichte der Philosophie III. Frankfurt am Main: Suhrkamp, 1971. Print. Vol. 20 of Werke.

Immerwahr, Raymond. "The Subjectivity or Objectivity of Friedrich Schlegel's Poetic Irony." Germanic Review 26.3 (1951): 173-91. Print.

Kierkegaard, Søren. The Concept of Irony. Trans. Howard Hong and Edna Hong. Princeton: Princeton UP, 1989. Print.

- Om Begrebet Ironi. 1841. Köbenhavn: Gyldendal, 1962. Print.

Lang, Berel. “The Limits of Irony.” New Literary History 27.3 (1996): 571-88. Print. 
Lukács, Georg. Die Theorie des Romans. Berlin: Cassirer, 1920. Print.

Matarrese, Craig B. "Satisfaction or Supersession? Expression, Rationality, and Irony in Hegel and Rorty." Clio: A Journal of Literature, History, and the Philosophy of History 36.1 (2006): 41-58. Print.

Millán-Zaibert, Elizabeth. Friedrich Schlegel and the Emergence of Romantic Philosophy. Albany: State U of New York P, 2007. Print.

Neuhouser, Frederick. Fichte's Theory of Subjectivity. Cambridge: Cambridge UP, 1990. Print.

Pippin, Robert. Modernism as a Philosophical Problem. Oxford: Blackwell, 1991. Print.

Pöggeler, Otto. Hegels Kritik der Romantik. 1956. München: Fink, 1998. Print.

Reid, Jeffrey. "Hegel on Schleiermacher and Postmodernity." Clio: A Journal of Literature, History, and the Philosophy of History 32.4 (2003): 457-72. Print.

Roy, Ayon. "From Deconstruction to Decreation: Wallace Stevens' Notes toward a Poetics of Nobility." Wallace Stevens Journal 29.2 (2005): 249-62. Print.

_. "Postmodern Convexity and Hegelian Dialectics in Ashbery's 'Self-Portrait in a Convex Mirror.'” Gingko Tree Review 4.1 (2007): 25-46. Print.

- "The Specter of Hegel in Coleridge's Biographia Literaria." Journal of the History of Ideas 68.2 (2007): 279-304. Print.

Rush, Fred. "Irony and Romantic Subjectivity." Philosophical Romanticism. Ed. Nikolas Kompridis. London: Routledge, 2006. 173-95. Print.
Schlegel, Friedrich. Charakteristiken und Kritiken I. Ed. Hans Eichner. München: Schöningh, 1967. Print. Vol. 2 of Kritische Ausgabe.

. Fragmente zur Poesie und Literatur. Ed. Hans Eichner. Paderborn: Schöningh, 1981. Print. Vol. 16 of Kritische Ausgabe.

. "On Incomprehensibility." Lucinde and the Fragments. Trans. Peter Firchow. Minneapolis: U of Minnesota P, 1971. 257-71. Print.

. Philosophical Fragments. Trans. Peter Firchow. Minneapolis: U of Minnesota P, 1991. Print.

. Philosophische Lehrjahre 1796-1806. Ed. Ernst Behler. München: Schöningh, 1963. Print. Vol. 18 of Kritische Ausgabe.

—. Philosophische Vorlesungen 1800-1807. Ed. JeanJacques Anstett. München: Schöningh, 1964. Print. Vol. 12 of Kritische Ausgabe.

Schleiermacher, Friedrich. On Religion: Speeches to Its Cultured Despisers. Trans. Richard Crouter. Cambridge: Cambridge UP, 1988. Print.

_ Über die Religion: Reden an die Gebildeten unter ihren Verächtern. Göttingen: Vandenhoeck, 1967. Print.

Stevens, Wallace. "Man Carrying Thing." The Collected Poems of Wallace Stevens. New York: Knopf, 1961. 350-51. Print.

Strohschneider-Kohrs, Ingrid. Die romantische Ironie in Theorie und Gestaltung. 1958. Tübingen: Niemeyer, 2002. Print.

Walzel, Oskar. "Methode? Ironie bei Friedrich Schlegel und bei Solger." Helicon 1 (1938): 33-50. Print. 